\title{
Presencia de don Enrique Molina en los festejos conmemorativos del Cuarto Centenario de la Universidad de San Marcos(*)
}

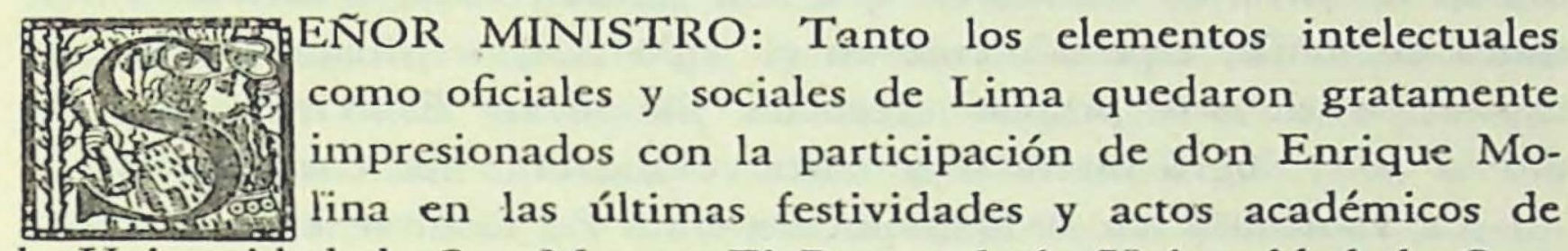
la Universidad de San Marcos. El Rector de la Universidad de Concepción, al igual que los demás Rectores de nuestras Universidades, fue especialmente invitado a concurrir a las ceremonias. El señor Molina traía no sólo la investidura de su propio cargo, sino también su vasto prestigio intelectual. Puede afirmarse que el señor Molina conquistó a los círculos académicos de Lima con su palabra sencilla y a la vez honda, y su simpatía personal. Su esposa colaboró dignamente en su misión de confraternidad intelectual.

La Semana Jubilar de San Marcos se inició con una actuación solemne en el Paraninfo de la Facultad de Medicina con asistencia del Presidente de la República, general Odría, y altas personalidades de todos los círculos. A petición expresa del Rector de San Marcos, don Pedro Dulanto, hizo uso de la palabra el señor Molina junto con los Rectores de las Universidades de Salamanca, de México, de

(*) Con este cpígrafe o suma, ba cnviado la Embajada de Chile en Lima la siguiente nota al Ministerio de Relaciones Exteriores de Santiago. 
Santo Domingo, de Fordham y del Brasil. El señor Molina se refirió al significado que tiene la Universidad de San Marcos en la cultura del Continente. Se refirió también a la Universidad de Concepción y a la misión de la Universidad en la hora actual. Las palabras del señor Molina fueron vivamente aplaudidas y se considera que su discurso fue el más medular de los pronunciados por los Rectores extranjeros.

El señor Molina participó con todo entusiasmo en los diversos actos y reuniones. La Facultad de Filosofía y Letras de la Universidad de San Marcos solicitó al señor Molina dictara una conferencia. El Rector de la Universidad de Concepción habló sobre "La Filosofía en Chile", en el salón de actos de la Facultad y frente a las autoridades universitarias, estudiantes y numeroso público. Hizo un estudio de las diversas tendencias que han caracterizado la actividad filosófica en Chile, especialmente en el siglo XX, terminando con una exposición de sus propias creencias filosóficas. Especialmente esta última parte logró interesar y hasta conmover a los circunstantes.

La Embajada en todo momento trató de facilitar la misión del señor Molina. El Embajador, señor Urrejola, ofreció un almuerzo, rindiendo un homenaje conjunto tanto al señor Molina como al Rector, señor Dulanto, simbolizando en esta forma la amistad que une a la Universidad de San Marcos con sus congéneres de Chile. En dicho almuerzo, el Embajador señor Urrejola hizo entrega de la condecoración del gobierno de Chile al Rector señor Dulanto. Ha dicho almuerzo asistieron el Vicepresidente y Presidente del Senado señor Héctor Boza, el Presidente de la Cámara de Diputados señor Claudio Fernández Concha, el Canciller señor Manuel Gallagher, el Ministro de Gobierno señor Ricardo de la Puente, el Ministro de Marina señor Roque Saldías, el Ministro de Educación Pública señor Juan Mendoza, el Embajador del Perú ante las Naciones Unidas scñor Víctor Andrés Belaúnde, el Secretario General de la Cancillería señor Javier Delgado Irigoyen, el Rector señor Pedro Dulanto, el Embajador del Brasil señor Luis de Faro, el Embajador de España señor Fernando María Castiella, el Embajador del Paraguay señor 
Fernando Vallejos, el Embajador de Francia señor Pierre Gilbert, el Embajador de Italia señor Enrico Bombieri, el Embajador de Venezuela señor Leonardo Altuvo Carrillo, el Embajador del Ecuador señor Gustavo Pérez Chiriboga, el Presidente del Quinto Congreso de Química señor Angel Maldonado, el Secretario General de la Universidad de San Marcos señor Roberto Mac Lean, el infrascrito y el señor H. Díaz Casanueva. Hicieron uso de la palabra en esta ocasión el Embajador señor Urrejola, el Rector señor Molina y el Rector señor Dulanto, quienes exteriorizaron sus sentimientos de colaboración universitaria y cultural chileno-peruano.

El señor Díaz Casanueva, antiguo alumno del señor Molina, le ofreció en su casa una comida, a la cual asistieron el Rector señor Dulanto, el Decano de la Facultad de Filosofía y Letras señor Aurelio Miró Quezada, el Presidente de la Sociedad de Filosofía señor Honorio Delgado, catedráticos, intelectuales y artistas, además de los miembros de la Embajada. Nuevamente en esta ocasión pronunciaron significativos discursos el Embajador señor Urrejola y los Rectores señores Molina y Dulanto, además de las palabras de salutación que dijo el sef̃or Díaz Casanueva.

El señor Molina quiso corresponder las atenciones recibidas ofreciendo un almuerzo en el Hotel Crillon, al cual asistieron el Rector señor Dulanto, profesores de la Universidad y miembros de la Embajada.

El Rector señor Dulanto expresó en todo momento su afecto por el señor Molina como también los profesores de la Universidad. Todos manifestaron su interés por una nueva visita a Lima del señor Molina, para el próximo mes de julio, con motivo de la celebración del Congreso Internacional de Filosofía.

Estimo que la presencia del señor Molina en el jubileo de la Universidad de San Marcos, ha redundado en bencficio de una mayor comprensión y de una más estrecha vinculación entre las Universidades chilenas y peruanas.

Dios guarde a U.S.-Guillermo Bianchi B., Lima, 30 de mayo de 1951. 